\title{
The peripartum period influenced the serum macromineral profile in mares
}

\author{
M. Bazzano ${ }^{1}$, E. Giudice ${ }^{2}$, C. Giannetto ${ }^{1}$, F. Fazio ${ }^{1}$, C. Scollo ${ }^{3}$, and G. Piccione ${ }^{1}$ \\ ${ }^{1}$ Department of Veterinary Sciences, University of Messina, Polo universitario dell' Annunziata, 98168, \\ Messina, Italy \\ ${ }^{2}$ Departement of Chemical, Biological, Pharmaceutical and Environmental Sciences, University of Messina, \\ Viale Ferdinando Stagno d'Alcontres 31, 98166, S. Agata-Messina, Italy \\ ${ }^{3}$ Independent veterinary practitioner, Catania, Italy \\ Correspondence to: G. Piccione (giuseppe.piccione@unime.it)
}

Received: 17 July 2015 - Revised: 23 November 2015 - Accepted: 12 January 2016 - Published: 27 January 2016

\begin{abstract}
Changes in metabolic requirements during pregnancy may produce nutritional imbalances predisposing mares to pathological conditions. Therefore, we aimed to examine changes in serum macrominerals during the peripartum period in mares. Fifteen pregnant mares (Group A) were monitored starting at the 263rd day of pregnancy until the 21st day after foaling. Seven non-pregnant and non-lactating mares were used as a control group (Group B). Group A was subjected to blood sampling within $24 \pm 12 \mathrm{~h}$ after parturition $(\mathrm{P})$ and then 7,14 and 21 days after foaling $(+1,+2,+3$ weeks, respectively). Group B was subjected to regular sampling throughout the study to ensure that seasonal changes had no significant effect on studied parameters. Serum samples were analysed for serum electrolytes including sodium $\left(\mathrm{Na}^{+}\right)$, potassium $\left(\mathrm{K}^{+}\right)$, calcium $\left(\mathrm{Ca}^{++}\right)$, phosphorus $\left(\mathrm{P}^{+}\right)$, chloride $\left(\mathrm{Cl}^{-}\right)$and magnesium $\left(\mathrm{Mg}^{++}\right)$. Two-way repeated measures of analysis of variance (ANOVA) was applied to evaluate significant effects of peripartum on electrolyte concentrations. Group A showed a decrease in $\mathrm{Cl}^{-}$concentrations $(P=0.011)$ after foaling and lower $\mathrm{P}^{+}$concentrations $(P=0.015)$ compared to Group $\mathrm{B}$ throughout the study. The linear regression model showed an increase in $\mathrm{Na}^{+}$concentrations $(P=0.002)$ and a gradual decrease in serum $\mathrm{Ca}^{++}(P=0.001)$ during pregnancy. Because the most significant changes in serum electrolytes occurred within 2 weeks before and 2 weeks after foaling, monitoring serum electrolyte concentrations would indicate whether the mare needs further mineral supplementation at this stage. The significant changes in a mare's macromineral profile that we observed over the peripartum provide enhanced knowledge about mineral interrelations and their modifications during specific physiological conditions such as late pregnancy and early postpartum.
\end{abstract}

\section{Introduction}

Almost every process of an animal's body depends for proper functioning on one or more of the mineral elements. Macrominerals such as calcium $\left(\mathrm{Ca}^{++}\right)$, phosphorus $\left(\mathrm{P}^{+}\right)$, sodium $\left(\mathrm{Na}^{+}\right)$, chloride $\left(\mathrm{Cl}^{-}\right)$, potassium $\left(\mathrm{K}^{+}\right)$and magnesium $\left(\mathrm{Mg}^{++}\right)$are needed for body structure as well as for maintaining the acid-base balance, fluid balance and transmembrane potential for cellular function, nerve conduction and muscle contraction (Cunha, 1980; Harvey et al., 2005). Minerals gain special importance during specific phases of animal life such as growth, reproduction and lacta- tion (Cunha, 1980). At these stages, maintaining a balanced amount of all minerals is necessary to preserve an animal's health (Lewis, 1995). The increased need for minerals during the peripartum period determines significant changes in mineral metabolism. This may produce a mineral imbalance leading to the onset of pathological conditions, for instance hypocalcaemia (Filipović et al., 2010). A study by Sevinga et al. (2002) found that Friesian mares with retained placenta showed lower serum $\mathrm{Ca}^{++}$levels compared to mares that shed the placenta spontaneously. A hypomagnesemic tetany responsive to $\mathrm{Mg}^{++}$and $\mathrm{Ca}^{++}$administration has been re- 
ported in lactating mares as well (Lewis, 1995). A few researchers have dealt with adjustments occurring in a mare's physiology during the peripartum period, focusing on clotting (Bazzano et al., 2014a) and haematological (Bazzano et al., 2014b, 2015) and biochemical profiles (Harvey et al., 2005; Aoki and Ishii, 2012; Satué and Montesinos, 2013; Bazzano et al., 2014c; Mariella et al., 2014). It has been shown that a series of hormonal and metabolic changes occur to modulate the maternal supply of energy and nutrients to the foeto-placental unit (Larsson et al., 2008). As gestation progresses, the direction and magnitude of these changes in maternal organism mainly depends on the increase in foetal metabolic requirements (Satué and Montesinos, 2013). Changes in a mare's metabolism continue during the postpartum period, when a certain amount of minerals is lost through milk production (Filipović et al., 2010): equine milk contains considerable concentrations of macrominerals that vary significantly during lactation (Salimei and Fantuz, 2012).

A general tendency of indiscriminately administrating mineral supplements to pregnant and lactating mares has developed in the last few years. Because little information on serum electrolytes is available for periparturient mares (Rook et al., 1997; Harvey et al., 2005), we aimed to determine whether physiological adjustments in serum macromineral concentrations occur when pregnant mares are fed a balanced diet. In addition, in this study we want to assess whether statistical correlations between studied minerals exist in pregnant and non-pregnant mares.

\section{Materials and methods}

\subsection{Animals}

Twenty-two clinically healthy mares (eight Italian Saddle Horses, eight Thoroughbreds, six Standardbreds), aged between 4 and 17 years, were considered in the present study. Animals from the same breeding centre, Istituto Incremento Ippico per la Sicilia (latitude $37.46^{\circ} \mathrm{N}$; longitude $14.93^{\circ} \mathrm{E}$ ), were housed in individual straw-bedded boxes under natural photoperiod. Fifteen pregnant mares (Group A) were monitored from $263 \pm 3$ days of pregnancy until 21 days after foaling; seven non-pregnant non-lactating mares served as controls (Group B). The mean gestation length was $340 \pm 9$ days. Following parturition the mares were subjected to clinical examinations over 3 consecutive days, and ultrasound examination (M-Turbo ${ }^{\circledR}$, FUJIFILM SonoSite, London, United Kingdom) was performed weekly to monitor the uterine involution and ovarian activity. The mares from Group A, with a mean body condition score (BCS) of 6.0-7.5, received $6 \pm 1 \mathrm{~kg} \mathrm{day}^{-1}$ dried grass hay (crude protein $9 \%$, crude fibre $35 \%$, Ca $0.4 \%, \mathrm{P} 0.23 \%$ ) and $5 \pm 0.5 \mathrm{~kg} \mathrm{day}^{-1}$ commercially available concentrates (crude protein $16 \%$, crude fat $6 \%$, crude fibre $7.35 \%$, ash $10.09 \%, \mathrm{Ca} / \mathrm{P} 1.5: 1, \mathrm{Na} 0.46 \%$, lysine $0.85 \%$, methionine $0.35 \%$, omega-3 $0.65 \%$ ). The mares from Group B, with a mean BCS of 5.5-7.0, received
$5 \pm 0.5 \mathrm{~kg} \mathrm{day}^{-1}$ hay and $2 \pm 0.5 \mathrm{~kg} \mathrm{day}^{-1}$ concentrates. Animals were moved to paddocks from 10:00 to 16:00 LT. All treatments, housing and animal care were carried out in accordance with the standards recommended by the EU Directive 2010/63/EU for animal experiments.

\subsection{Data collection}

Sampling was performed weekly in the morning (07:00 LT) until the time of parturition. A total of 12 samples was collected from pregnant mares before parturition $(-12$ to $-1)$. Furthermore, animals were subjected to blood sampling within $24 \pm 12 \mathrm{~h}$ from parturition $(\mathrm{P})$ and then 7,14 and 21 days after foaling $(+1,+2,+3$ weeks, respectively). The same blood sampling that was carried out in Group A was also carried out in Group B to ensure that seasonal changes had no significant effect on studied parameters. Blood samples were collected by jugular venipuncture into $10 \mathrm{~mL}$ vacuum tubes containing clot activators (Terumo Corporation, Tokyo, Japan). Samples were centrifuged at $1300 \mathrm{~g}$ for $10 \mathrm{~min}$, within $30 \mathrm{~min}$ of collection, and the obtained sera were stored at $-20^{\circ} \mathrm{C}$ until analysis. Serum concentration of calcium $\left(\mathrm{Ca}^{++}\right)$, phosphorus $\left(\mathrm{P}^{+}\right)$, chloride $\left(\mathrm{Cl}^{-}\right)$and magnesium $\left(\mathrm{Mg}^{++}\right)$were assessed by means of UV spectrophotometry (Slim, SEAC, Italy), while sodium $\left(\mathrm{Na}^{+}\right)$and potassium $\left(\mathrm{K}^{+}\right)$were analysed using semiautomatic flame photometry (FP 20, SEAC, Italy). Commercially available kits were used for macromineral detection.

\subsection{Statistical analysis}

All data are expressed as means \pm standard error of the mean (SEM). Data were tested for normality using the ShapiroWilk normality test. Two-way repeated measures of analysis of variance (ANOVA) was applied to evaluate significant effects of peripartum on electrolyte concentrations. When significant differences were found, Bonferroni's post hoc comparison was applied. The Pearson test was performed to assess significant correlations between the selected electrolytes in pregnant and control groups. A linear regression model $(y=a+b x)$ was applied to determine the degree of correlation between each electrolyte and the time before and after foaling in Group A.

$P$ values $<0.05$ were considered statistically significant. Statistical analysis was performed using the STATISTICA software package (STATISTICA 7 Stat Software Inc., Tulsa, Oklahoma).

\section{Results}

None of the mares included in Group A showed clinical signs of disease during their pregnancy and postpartum. The mares delivered healthy, viable full-term foals, without human assistance. They passed a normal and intact placenta sponta- 

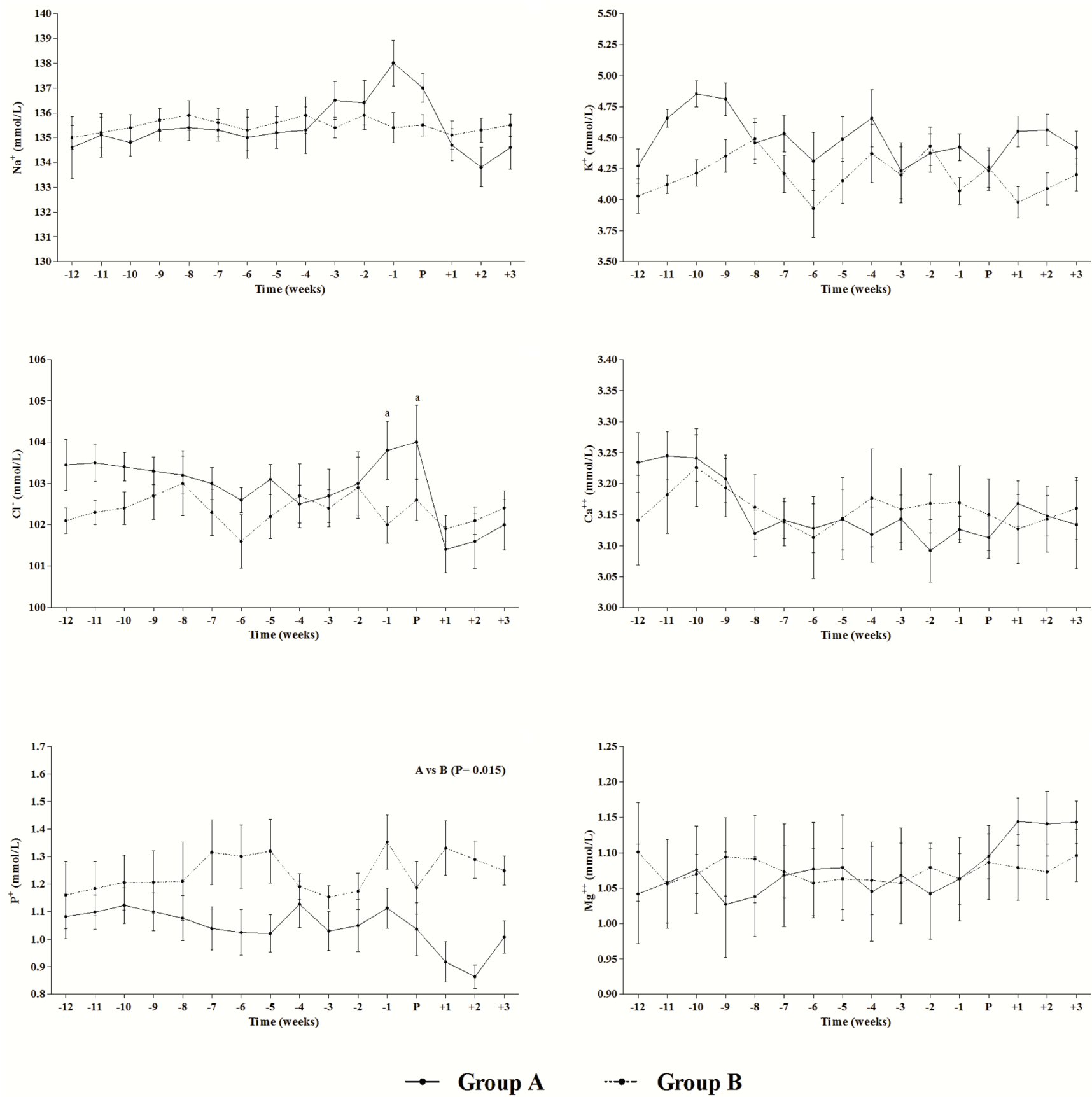

$\cdots$-.- Group B

Figure 1. Means \pm standard error of the mean (SEM) of $\mathrm{Na}^{+}, \mathrm{K}^{+}, \mathrm{Cl}^{-}, \mathrm{Ca}^{++}, \mathrm{P}^{+}$and $\mathrm{Mg}^{++}$obtained from pregnant $(\mathrm{Group} \mathrm{A})$ and control (Group B) mares. Time is expressed as weeks before $(-12$ to -1$)$ and after $(+1$ to +3$)$ parturition (P). Significance: "a" vs. +1 and $+2(P<0.05)$.

neously within $2 \mathrm{~h}$ and achieved the complete involution of the uterus within 2 weeks after foaling.

The Shapiro-Wilk analysis showed a normal distribution of the data. Figure 1 shows means \pm SEM of studied parameters obtained from pregnant mares and the control group. Group A showed significant changes in $\mathrm{Cl}^{-}$concentration $(P=0.011)$ that rapidly decreased during the first 2 weeks following parturition compared to the week before foaling and the time of foaling $(-1$ and $P$ vs. $+1+2)$. A significant effect of pregnancy was found on serum $\mathrm{P}^{+}(P=0.015)$, pregnant mares showed lower $\mathrm{P}$ concentrations than nonpregnant mares throughout the monitored period. Statistical correlations between electrolytes calculated for Groups A and B (Table 1) are displayed graphically in Fig. 2. The lin- 
Table 1. Coefficients of correlation between sodium $\left(\mathrm{Na}^{+}\right)$, potassium $\left(\mathrm{K}^{+}\right)$, Chloride $\left(\mathrm{Cl}^{-}\right)$, calcium $\left(\mathrm{Ca}^{++}\right)$, phosphorus $\left(\mathrm{P}^{+}\right)$and magnesium $\left(\mathrm{Mg}^{++}\right)$calculated for pregnant (Group A) and control (Group B) mares. Significant correlations $(P<0.05)$ are indicated in bold letters.

\begin{tabular}{|c|c|c|c|c|c|}
\hline & $\overline{\mathrm{K}^{+}}$ & $\mathrm{Cl}^{-}$ & $\mathrm{Ca}^{++}$ & $\mathrm{P}^{+}$ & $\mathrm{Mg}^{++}$ \\
\hline \multicolumn{6}{|c|}{ Group A } \\
\hline $\begin{array}{l}\mathrm{Na}^{+} \\
\mathrm{K}^{+} \\
\mathrm{Cl}^{-} \\
\mathrm{Ca}^{++} \\
\mathrm{P}^{+}\end{array}$ & $r=-0.185$ & $\begin{array}{l}r=\mathbf{0 . 2 0 1} \\
r=0.103\end{array}$ & $\begin{array}{r}r=-0.095 \\
r=\mathbf{0 . 2 5 4} \\
r=\mathbf{0 . 3 5 4}\end{array}$ & $\begin{array}{r}r=0.026 \\
r=-0.041 \\
r=-0.051 \\
r=-0.071\end{array}$ & $\begin{array}{r}r=0.056 \\
r=-0.058 \\
r=\text { boldsymbol }-\mathbf{0 . 1 7 4} \\
r=-0.030 \\
\boldsymbol{r}=\mathbf{0 . 1 7 4}\end{array}$ \\
\hline \multicolumn{6}{|c|}{ Group B } \\
\hline $\begin{array}{l}\mathrm{Na}^{+} \\
\mathrm{K}^{+} \\
\mathrm{Cl}^{-} \\
\mathrm{Ca}^{++} \\
\mathrm{P}^{+}\end{array}$ & $r=$ boldsymbol -0.241 & $\begin{array}{l}r=0.208 \\
r=0.432\end{array}$ & $\begin{array}{r}r=\text { boldsymbol }-\mathbf{0 . 4 8 6} \\
r=0.739 \\
r=\mathbf{0 . 4 3 5}\end{array}$ & $\begin{array}{r}r=\mathbf{0 . 2 8 5} \\
r=\text { boldsymbol }-\mathbf{0 . 1 8 7} \\
r=\text { boldsymbol }-\mathbf{0 . 1 8 9} \\
r=\text { boldsymbol }-\mathbf{0 . 2 4 9}\end{array}$ & $\begin{aligned} r=\text { boldsymbol } & -\mathbf{0 . 2 0 9} \\
r & =\mathbf{0 . 5 0 6} \\
r & =\mathbf{0 . 4 3 1} \\
r & =\mathbf{0 . 4 8 4} \\
r=\text { boldsymbol } & -\mathbf{0 . 2 1 0}\end{aligned}$ \\
\hline
\end{tabular}

Group A

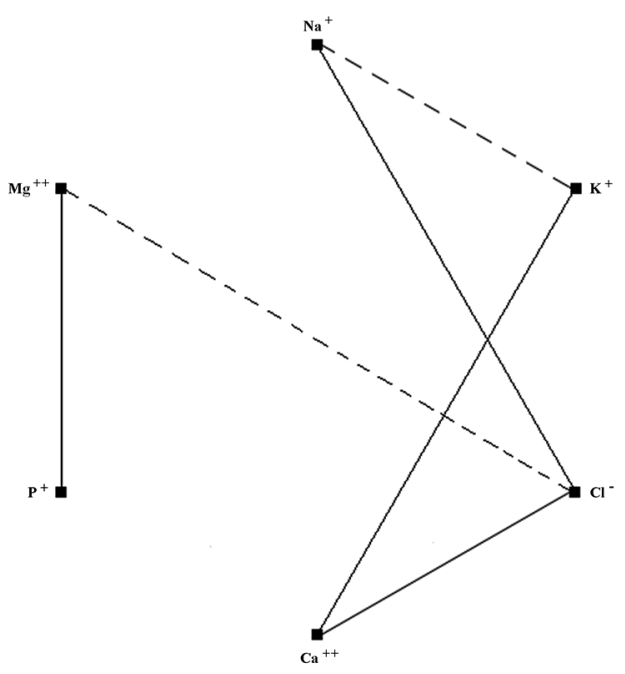

Group B

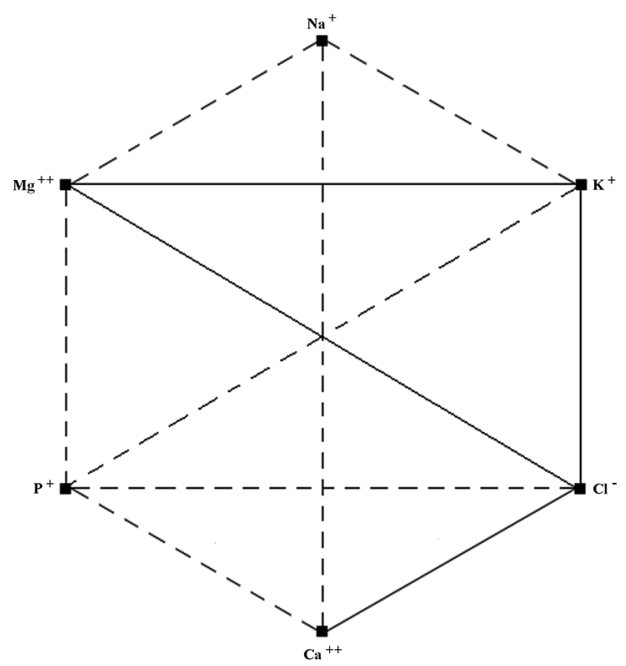

Figure 2. Graphical representation of statistical correlations obtained between studied electrolytes in pregnant (Group A) and control (Group B) mares. Continuous lines indicate positive correlations and dotted lines indicate negative correlations.

ear regression model showed a progressive increase in $\mathrm{Na}^{+}$ concentrations $(P=0.002)$ and a gradual decrease in serum $\mathrm{Ca}^{++}(P=0.001)$ during pregnancy (Fig. 3$)$.

\section{Discussion}

In the present study significant changes in the concentration of $\mathrm{Na}^{+}, \mathrm{Cl}^{-}, \mathrm{Ca}^{++}$and $\mathrm{P}^{+}$occurred during the last 3 months of pregnancy and the first 3 weeks postpartum in the mare.

The progressive increase in serum $\mathrm{Na}^{+}$which we observed during the last month of pregnancy accords with a study by Harvey et al. (2005), which reported a peak in $\mathrm{Na}^{+}$concentration around the time of foaling. These changes in $\mathrm{Na}^{+}$ trend may be related to the renin-angiotensin-aldosterone system (RAAS) of the mare that directly controls $\mathrm{Na}^{+}$excretion, internal homeostasis and blood pressure. The effects of pregnancy on RAAS function have been investigated in humans (Weir et al., 1975; Bentley-Lewis et al., 2005), dogs (Robb et al., 1970) and mares (Satué and Domingo, 2011). In particular, an increase in aldosterone concentration was found in mares during late pregnancy (Satué and Domingo, 2011). This leads to a better renal conservation of $\mathrm{Na}^{+}$and water to favour the expansion of the foeto-placental unit and to guarantee the correct nutrient intake of the foetus, as well as the appropriate homeostasis and blood pressure between mother and foetus. In our study the highest $\mathrm{Na}^{+}$concentrations were recorded at the last blood sampling preceding parturition. Since, $\mathrm{Na}^{+}$occurs in considerable amounts in 

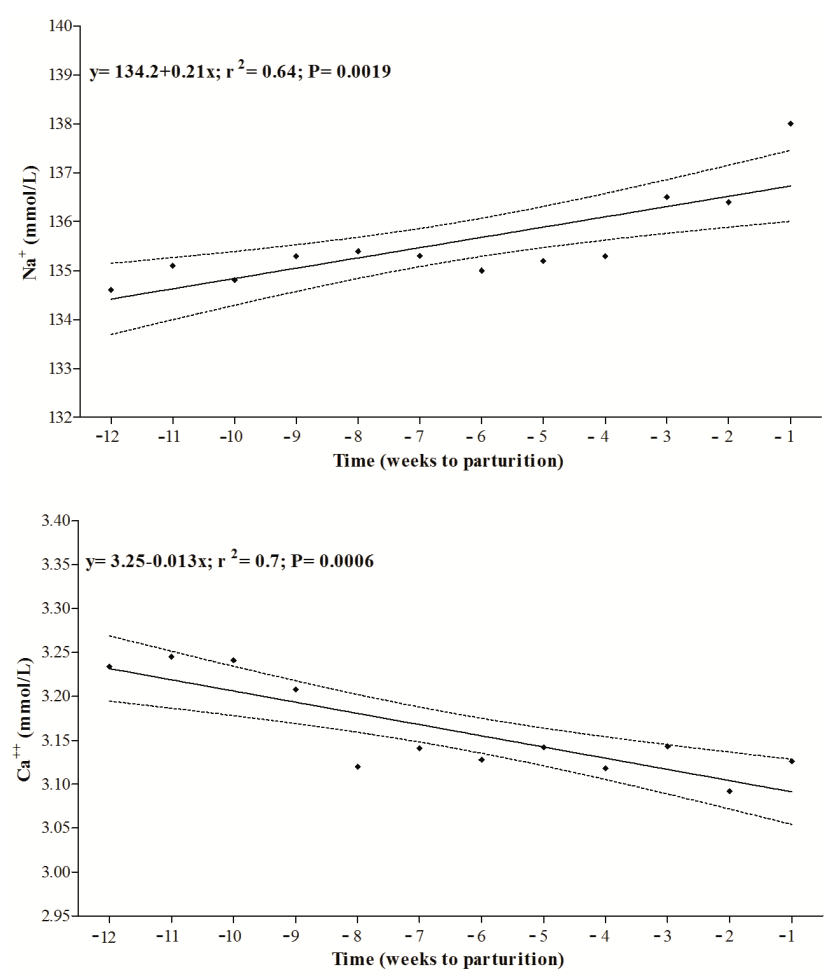

Figure 3. Linear regression model of $\mathrm{Na}^{+}$and $\mathrm{Ca}^{++}$recorded during pregnancy in Group A. Time is expressed as weeks to parturition.

muscles and plays a vital role in muscle contraction (Cunha, 1980), our finding may represent a physiological adjustment at the time of foaling when forceful abdominal contractions are necessary for the expulsion of the foal (Daels et al., 1991). The significant decrease in $\mathrm{Cl}^{-}$concentration recorded in our study after foaling accords with the findings of Harvey et al. (2005) that showed a progressive reduction in serum $\mathrm{Cl}^{-}$following parturition. This reduction in $\mathrm{Cl}^{-}$ levels may be due to the loss of this electrolyte with lactation as a mare's milk contains from 300 to $640 \mathrm{ppm}$ of $\mathrm{Cl}^{-}$ (Cunha, 1980). In addition, although not reported in horses, hypochloremia without serum $\mathrm{Na}^{+}$depletion has been reported in lactating cows (Lewis, 1995). In the present study significant changes in the serum levels of $\mathrm{Ca}^{++}$and $\mathrm{P}^{+}$were also found. The progressive decrease recorded in $\mathrm{Ca}^{++}$concentration until the time of foaling accords with Berlin and Aroch (2009), who found lower serum $\mathrm{Ca}^{++}$in pregnant mares compared to non-pregnant horses. A possible explanation lies in the equine placenta containing a Ca-binding protein that increases $\mathrm{Ca}^{++}$transfer from the mare to the foetus in order to meet the needs for the foetal skeleton mineralization (Wooding et al., 2000). Together with $\mathrm{Ca}^{++}, \mathrm{P}^{+}$plays a key role in several body functions such as bone and energy metabolism. These electrolytes comprise about $70 \%$ of the mineral content of the body and up to $50 \%$ of the minerals in milk. Most of the foetal $\mathrm{Ca}^{++}$and $\mathrm{P}^{+}$deposition occurs dur- ing the last 2 months of gestation, which suggests that most of the skeletal development occurs at that time (Kavazis et al., 2002). This foetal use of minerals and the close relation between the $\mathrm{Ca}^{++}$and $\mathrm{P}^{+}$metabolisms (Rosol and Capen, 1997) may explain the lower $\mathrm{P}^{+}$concentrations in periparturient mares compared to the control group. Although previous studies dealt with the assessment of serum electrolytes in periparturient mares (Rook et al., 1997; Harvey et al., 2005), to the best of the authors' knowledge, this is the first study that statistically assesses the correlation coefficients between serum macrominerals in pregnant and non-pregnant mares. We found that every mineral was significantly correlated to another mineral in non-pregnant mares. In effect, serum electrolytes should be considered as a group rather than individually. As the intake of a mineral increases above that needed, the part not absorbed may bind other minerals, decreasing their absorption and possibly resulting in a deficiency of these minerals (Lewis, 1995). However, Group A did not show the same statistical correlations we found in Group B except $\mathrm{Na}^{+} / \mathrm{Cl}^{-}$and $\mathrm{Ca}^{++} / \mathrm{Cl}^{-}$. Opposite correlations $\mathrm{Mg}^{++} / \mathrm{Cl}^{-}$and $\mathrm{Mg}^{++} / \mathrm{P}^{+}$were found in pregnant mares compared to the control group. These changes in mineral interrelations may result from physiological adjustments of the mineral metabolism occurring in the mare during both late gestation and lactation. During the peripartum period the mare has to cope with remarkable mineral requirements from the developing foetus as well as the growing foal, particularly in relation to $\mathrm{Ca}^{++}$and $\mathrm{P}^{+}$(Summer et al., 2004).

Contrary to the previous studies performed over a limited period of time (Rook et al., 1997) or with a limited frequency of sampling (Harvey et al., 2005), we focused on the last trimester of pregnancy and the first 3 weeks after foaling, using a weekly sampling that allowed us to detect transient changes in mineral serum concentrations. Because the most significant changes in serum electrolytes occurred within 2 weeks before and 2 weeks after foaling, monitoring serum electrolyte concentrations would indicate whether the mare needs further mineral supplementation at this stage. The significant changes in a mare's macromineral profile which we found over the peripartum provide enhanced knowledge about mineral interrelations and their modifications during specific physiological conditions such as late pregnancy and early postpartum.

Author contributions. All authors have made substantial contributions to each step of experimental procedure and manuscript preparation. Specific contributions are as follows: M. Bazzano designed the experiment and C. Scollo performed the sampling. C. Giannetto performed the laboratory analysis and F. Fazio analysed the data. M. Bazzano and E. Giudice prepared the paper. G. Piccione supervised all stages of the experimental study.

Edited by: A.-E. Freifrau von Tiele-Winckler Reviewed by: M. Gianesella and S. Marafioti 


\section{References}

Aoki, T. and Ishii, M.: Hematological and Biochemical Profiles in Peripartum Mares and Neonatal Foals (Heavy Draft Horse), J. Equine Vet. Sci., 32, 170-176, 2012.

Bazzano, M., Giannetto, C., Fazio, F., Marafioti, S., Giudice, E., and Piccione, G.: Hemostatic profile during late pregnancy and early postpartum period in mares, Theriogenology, 81, 639-643, 2014a.

Bazzano, M., Giannetto, C., Fazio, F., Rizzo, M., Giudice, E., and Piccione, G.: Physiological adjustments of haematological profile during the last trimester of pregnancy and the early post partum period in mares, Anim. Reprod. Sci., 149, 199-203, 2014 b.

Bazzano, M., Giannetto, C., Fazio, F., Arfuso, F., Giudice, E., and Piccione, G.: Metabolic profile of broodmares during late pregnancy and early post-partum, Reprod. Dom. Anim., 49, 947-953, 2014c.

Bazzano, M., Arfuso, F., Giudice, E., Di Pietro, S., and Piccione, G.: Platelet aggregation percentage increased in healthy broodmares during the peripartum, J. Equine Vet. Sci., 35, 573-576, 2015.

Bentley-Lewis, M. D., Graves, S. W., and Seely, E. W.: The renin aldosterone response to stimulation and suppression during normal pregnancy, Hypertens. Pregnancy, 24, 1-16, 2005.

Berlin, D. and Aroch, I.: Concentrations of ionized and total magnesium and calcium in healthy horses: Effects of age, pregnancy, lactation, pH and sample type, Vet. J., 181, 305-311, 2009.

Cunha, T. J. (Ed.): Mineral requirements of the horse, in: Horse feeding and nutrition, Academic Press, New York, NY, 59-110 1980.

Daels, P. F., Hughes, J. P., and Stabenfeldt, G. H.: Reproduction in horses, in: Reproduction in domestic animals, edited by: Cupps, P. T., 4th Edn., Academic Press Inc., San Diego, CA, 413-444, 1991.

Filipović, N., Stojević, Z., Prvanović, N., and Tucek, Z.: The influence of late pregnancy and lactation on bone metabolism in mares, Res. Vet. Sci., 88, 405-410, 2010.

Harvey, J. W., Pate, M. G., Kivipelto, J., and Asquith, R. L.: Clinical biochemistry of pregnant and nursing mares, Vet. Clin. Path., 34, 248-254, 2005.

Kavazis, A. N., Kivipelto, M. S. J., and Ott, E. A.: Supplementation of broodmares with copper, zinc, iron, manganese, cobalt, iodine, and selenium, J. Equine Vet. Sci., 22, 460-464, 2002.

Larsson, A., Palm, M., Hansson, L. O., and Axelsson, O.: Reference values for clinical chemistry test during normal pregnancy, BJOG-Int. J. Obstet. Gy., 115, 874-881, 2008.
Lewis, L. D. (Ed.): Equine clinical nutrition: feeding and care, Williams \& Wilkins, Philadelphia, 1995.

Mariella, J., Pirrone, A., Gentilini, F., and Castagnetti, C.: Hematological and biochemical profiles in Standardbred mares during peripartum, Theriogenology, 81, 526-534, 2014.

Robb, C. A., Davis, J. O., Johnson, J. A., Blaine, E. H., Schneider, E. G., and Baumber, J. S.: Mechanisms regulating the renal excretion of sodium during pregnancy, J. Clin. Invest., 49, 871-880, 1970.

Rook, J. S., Braselton, W. E., Nachreiner, R. F., Lloyd, J. W., Shea, M. E., Shelle, J. E., and Hitzler, P. R.: Multi-element assay of mammary secretions and sera from periparturient mares by inductively coupled argon plasma emission spectroscopy, Am. J. Vet. Res., 58, 376-378, 1997.

Rosol, T. J. and Capen, C. C.: Calcium-regulating hormones and disease of abnormal mineral (calcium, phosphorus, magnesium) metabolism, in: Clinical biochemistry of domestic animals, edited by: Kaneko, J. J., Harvey, J. W., and Bruss, M. L., 5th Edn., Academic Press, San Diego, CA, 619-702, 1997.

Salimei, E. and Fantuz, F.: Equid milk for human consumption, Int. Dairy J., 24, 130-142, 2012.

Satué, K. and Domingo, R.: Longitudinal study of the renin angiotensin aldosterone system in purebred Spanish broodmares during pregnancy, Theriogenology, 75, 1185-1194, 2011.

Satué, K. and Montesinos, P.: Plasma biochemistry in pregnant Spanish purebred broodmares, Comp. Clin. Pathol., 22, 113-117, 2013.

Sevinga, M., Barkema, H. W., and Hesselink, J. W.: Serum calcium and magnesium concentrations and the use of calciummagnesium-borogluconate solution in the treatment of Friesian mares with retained placenta, Theriogenology, 57, 941-947, 2002.

Summer, A., Sabbioni, A., Formaggioni, P., and Mariani, P.: Trend in ash and mineral element content of milk from Haflinger nursing mares throughout six lactation months, Livest. Prod. Sci., 88, 55-62, 2004.

Weir, R. J., Brown, J. J., Fraser, R., Lever, A. F., Logan, R. W., McIlwaine, G. M., Morton, J. J., Robertson, J. I., and Tree, M.: Relationship between plasma rennin, rennin substrate, angiotensin II, aldosterone and electrolytes in normal pregnancy, J. Clin. Endocrinol. Metab., 40, 108-115, 1975.

Wooding, F. B. P., Morgan, G., Fowden, A. L., and Allen, W. R.: Separate sites and mechanisms of placental transport of calcium, iron and glucose in the equine placenta, Placenta, 21, 635-645, 2000 . 